\title{
O MENDIGO CEGO - CONTO DE ELIYAHU MEIDANEK
}

\section{THE BLIND BEGGAR - A SHORT STORY BY ELIYAHU MEIDANEK}

\author{
Gabriel Steinberg*
}

\begin{abstract}
Resumo: Este texto apresenta a tradução do conto Hakabtsan Hayiver (O Mendigo Cego), do escritor em língua hebraica Eliyahu Meidanek. Em sua curta trajetória, Meidanek demonstrou grande domínio do hebraico literário, e ao igual que outros escritores e intelectuais da época, contribuiu para a popularização da língua já que seus contos eram publicados nos jornais hebraicos que circulavam na época pela Europa Oriental.
\end{abstract}

Palavras-chave: Literatura judaica. Língua hebraica. Diáspora judaica.

\begin{abstract}
This text presents the translation of the short story Hakabtsan Hayiver (The Blind Beggar), by the Hebrew writer Eliyahu Meidanek. In his short trajectory, Meidanek demonstrated great mastery of literary Hebrew, and like other writers and intellectuals of the time, contributed to the popularization of the language since his stories were published in the Hebrew newspapers that circulated at the time in Eastern Europe.
\end{abstract}

Keywords: Jewish literature. Hebrew language. Jewish diaspora.

O jovem escritor Eliyahu Meidanek nasceu na Ucrânia, então parte do Império Russo, em 1882. Recebeu educação judaica tradicional enquanto demonstrava grande interesse pelos estudos seculares. A partir dos 13 anos, começou a escrever para o jornal judaico em língua russa Voskhod. Aos 17 anos, estabeleceu-se em Odessa, ${ }^{1}$ que concentrava uma parte considerável da intelectualidade judaica, onde entrou em contato com alguns renomados escritores, e foi especialmente influenciado pelo poeta Jeoshua Davidovich. Começou a publicar contos no jornal Haschiloah, publicação mensal em

\footnotetext{
*Gabriel Steinberg é professor no Departamento de Letras Orientais da Faculdade de Filosofia, Letras e Ciências Humanas da Universidade de São Paulo. E-mail: <steinberg1818@usp.br>.

${ }^{1}$ Odessa - Cidade portuária ucraniana às margens do Mar Negro. No século XIX era a terceira cidade mais importante do Império Russo atrás apenas de Moscou e São Petersburgo. Os judeus se estabeleceram na cidade no século XIX quando esta se tornou um porto livre. Calcula-se que a população judaica somava mais de 160 mil pessoas no final do século, o que a tornou a maior cidade de população judaica do Império. Os judeus da cidade sofreram vários pogroms em 1881 e 1905. No final do século XIX, consolidou-se na cidade o movimento do iluminismo judaico, e muitos judeus passaram a frequentar escolas e universidades e também foi fundada ali uma escola judaica moderna. Também nessa época foi criado um centro de apoio ao movimento sionista, e Odessa se transformou numa importante base de atuação do movimento nacionalista judaico. Foi ali que atuaram alguns dos grandes escritores sionistas e pioneiros da moderna literatura hebraica, entre eles Bialik e Klausner.
} 
língua hebraica, criada por Ahad Ha'am em Odessa, em 1896. Profundamente abalado pelo pogrom de Kishnev ocorrido em 1903, cometeu suicídio em 22 de maio de 1904, aos 22 anos.

O conto aqui apresentado e traduzido diretamente do hebraico, foi publicado pela primeira vez em Odessa, em 1902, precisamente no jornal Haschiloah. Meidanek nasceu na mesma época em que ocorreu a $1^{\mathrm{a}}$ aliyá, a primeira onda imigratória de jovens judeus oriundos do Império Russo rumo à Terra de Israel, e morreu em 1904, ano em que se iniciou a $2^{\mathrm{a}}$ aliyá, também motivada pela ocorrência de pogroms. Meidanek viveu numa época em que o movimento sionista estava tomando corpo e, também, o renascimento da língua hebraica. Esta tendência era verificada na publicação de vários periódicos em hebraico, em especial na Europa Oriental, e também no renascimento da língua hebraica falada na Terra de Israel.

Num período em que a língua estava se solidificando e novas palavras eram constantemente criadas, a narrativa de Meidanek flui impressionando o leitor pelo domínio da língua que o jovem escritor possuía. O conto aqui apresentado tem como personagem principal, Abrão, um professor que junto com sua modesta família, acabou perdendo seu meio de sustento durante um incêndio. Obrigado a recorrer à ajuda de parentes que estavam pouco propensos a ajudá-lo, Abrão começa a pedir ajuda, já que fora injustiçado pela vida, até que decide tornar-se um mendigo. Vilipendiado e ofendido pela própria família que enxerga em sua atividade uma grande ofensa à sua honra, Abrão decide abandonar o lar, a família e sua vida de mestre, e se lança ao mundo atrás de reconhecimento e dignidade. Ele não compreende como as pessoas veem sua atividade como algo que denigre a honra, mas ao mesmo tempo, essas pessoas se mostram dispostas a usufruir do dinheiro obtido nessa atividade menosprezada.

\section{O Mendigo Cego ${ }^{2}$}

Aconteceu um dia que a casa do professor Abrão foi consumida pelo fogo, e nessa casa se encontrava seu humilde quarto e também a pequena loja de sua esposa, e graças a esses espaços, os dois conseguiam se sustentar com grande dificuldade. Por isso, ambos decidiram que Abraão iria procurar Nahman, um rico parente que morava numa cidade

2 MEIDANEK, Eliyahu. Hakabtsan Hayiver. Proyect Ben Yehuda. Disponível em: <https://benyehuda.org/read/4793>. Acesso em 10/07/2020. 
distante, a fim de pedir sua ajuda na reconstrução da casa que se queimara, e também, se possível, dinheiro que seria utilizado na compra de produtos para uma nova loja, e assim, com a ajuda do Deus Todo-Poderoso, e com o passar do tempo, eles haveriam de lhe devolver o empréstimo e ainda com um reconhecido agradecimento. Com grande esforço conseguiram a soma necessária para as despesas da viagem. Abraão vestiu o capote tradicional usado no Shabat, que por acaso foi salvo do incêndio, e iniciou a viagem até a casa do parente rico, que era filho da tia de sua esposa.

O cocheiro que o levou até a cidade do parente, também o levou até sua espaçosa e bela casa. Depois de permanecer por um longo tempo fora, Abrão abriu a porta da casa e foi até um dos quartos, quando se deparou com a dona da casa, uma mulher rechonchuda. Ele a reconheceu imediatamente, seu nome era Rebeca, porém ela não o reconheceu porque só o vira uma única vez na vida, muitos anos atrás, durante o casamento de um dos seus parentes mútuos, e ele, não era um dos convidados de honra.

- Você não está me reconhecendo? - perguntou-lhe Abrão com uma risada amigável - mas eu a reconheci imediatamente. Eu sou Abrão, carne de vossa carne, o mestre daquela certa cidade.

- Oh, você não é Abrão, o parente de Nahman? - disse a mulher - Se eu não estou enganada, eu o vi junto a sua esposa no casamento do filho da minha cunhada, não foi? E como está sua esposa? Sente-se numa cadeira. E como você está?

- Graças a Deus, estamos vivos e saudáveis. Minha esposa lhe envia saudações, assim como a seus queridos filhos - respondeu Abrão, movido por afeição e amizade Mas você está perguntando como estamos? - e ele acrescentou depois de um momento: estamos profundamente amargurados, pois por acaso vocês não ouviram nada a respeito da tragédia que se abateu sobre nós?

- E o que lhes aconteceu? - perguntou Rebeca surpresa.

- Então vocês nada ouviram falar? Pois um grande desastre se abateu sobre nós. Há cerca de dois meses atrás, um terrível incêndio atingiu nossa cidade. Uma rua inteira foi queimada e também nossa casa e a loja e tudo o que ela continha, e nós ficamos sem nada. Oxalá que vocês nunca saibam de tamanha desgraça.

- Que o Senhor Deus nos proteja - murmurou Rebeca - que não saibamos, que não saibamos, mas então o que você está fazendo agora?

- E o que eu posso fazer? - respondeu Abrão com um suspiro - afinal, estamos passando fome, ficamos sem o quarto para ministrar as aulas e sem a loja, nossa vida agora ficou ruim e muito amarga. 
- Inúmeros são os problemas para o Santo, bendito seja Ele, que não saibamos de desgraças - disse Rebeca - Pois Ele dirige o mundo conforme Sua vontade.

- E onde está Reb Nahman? Ele foi para algum lugar? - perguntou Abrão a Rebeca depois que a conversa se deteve por um instante.

- Sim, Nahman foi atrás de um negócio - respondeu a parente - Nahman está sempre ocupado e preocupado. Ocupar-se com o comércio não é tarefa fácil. O comércio deixa o cérebro exausto, e ainda existem nossos concorrentes, por isso ele não tem descanso algum, ele não come e nem dorme adequadamente, ele corre e viaja dia e noite, até finalmente conseguir o sustento. O comércio anda mal nestes tempos. Ninguém está bem agora, nem os ricos e nem os pobres. Esta é uma época difícil que se abateu sobre o mundo.

A lamúria da parente a respeito dos tempos difíceis causaram forte impressão sobre Abrão. Mas ele tentou se consolar, afinal ela era uma estranha, o verdadeiro parente ainda estava para vir. E enquanto ele refletia, entrou na sala um jovem de uns vinte anos, baixo, rechonchudo como uma mãe, e de rosto vermelho. Ele chegou elegantemente vestido e segurava em sua mão direita um lindo bastão. O jovem olhou brevemente para Abrão, que nesse instante estava sentado à mesa, e virou-se para a mãe com uma pergunta que Abrão não conseguiu ouvir.

- Este é seu filho mais velho? - perguntou Abrão, que ficou encantado com a visão do jovem elegante e saudável, sentindo certo apreço no coração.

- Meu filho é este, meu filho mais velho - respondeu a mulher de bom grado. - Ele já está noivo, e sua noiva toca piano, conhece a língua da França, e o sogro é um dos mais famosos comerciantes da região.

- É assim mesmo? - Abrão ficou surpreso, porém feliz pela riqueza e honra do filho de seu parente.

Mas o jovem sequer prestou atenção à sua presença, ele se dirigiu para os aposentos sem perguntar quem era Abrão, e sua mãe nada lhe disse a respeito do visitante.

Depois de um tempo, o parente de Abrão chegou. Era um homem alto e magro e vestia um casaco que chegava até os tornozelos. Ao entrar na sala, Abrão levantou-se do assento e olhou para seu rosto com um leve sorriso e reverência, esperando ser reconhecido. E de fato o parente o reconheceu imediatamente, apesar de apenas tê-lo visto duas vezes na vida. 
- Ah, Abrão, que a paz esteja convosco! E o que o trouxe até aqui? - Perguntou depois de colocar sua bengala num canto e após colocar seu solidéu de seda sobre a cabeça em vez do chapéu que havia removido.

- O que me trouxe até aqui? - respondeu Abrão enquanto permanecia em pé, visivelmente constrangido - Pois eu vim ... então ... mas já estou indo, adeus!.

Nesse momento pareceu como se Nahman tivesse esquecido da presença de Abrão, e enquanto eles ainda conversavam, passou a falar com sua esposa sobre vários assuntos, e então Abrão sentou-se de lado e os observou em silêncio. Quando Nahman terminou a conversa com sua esposa, ele olhou para Abrão, e como se tivesse lembrado de sua presença ali, lhe perguntou:

- E como você está? Você é professor, não é?

- Sim, eu ensino, sou professor.

- E você está numa boa situação?

- Eu tinha uma posição, mas... Que vocês não passem por algo assim! Há pouco tempo perdi tudo o que tinha num enorme incêndio que se alastrou pela nossa cidade. Trinta casas foram queimadas, incluindo a minha e com ela se foi também nossa loja.

- Assim ocorreu? - perguntou Nahman surpreso. - Então tudo se queimou? Lamento por você! Os incêndios sempre ocorrem nas pequenas aldeias, cujas casas apertadas estão sempre muito juntas, e os telhados estão sempre cobertos de palha e, para piorar a situação, as chaminés nunca são limpas nesses lugares, e o batalhão dos bombeiros é algo inexistente, e quando o fogo irrompe, ele se espalha rapidamente de uma casa para outra. E quando isso ocorre, não há salvador para remediar a situação.

Abrão deu um leve sorriso, visivelmente constrangido.

- E o que importa a Deus se esse pobre homem vivia em paz e sustentava com muita dificuldade sua esposa e filhos? A propósito, quantos filhos você tem?

- Cinco, e que tenham uma vida longa.

- Isto confirma o que eu digo: cinco filhos ele tem - e voltando-se para sua esposa, acrescentou: - nada poderia ser pior. - E então disse à esposa - Rebeca, ordene que seja servida a mesa, já está na hora.

- Vá e lave suas mãos também, - ordenou Nahman a Abrão. Abrão lavou as mãos, sentou-se num dos cantos da mesa e comeu em silencio tudo o que lhe deram, pois as pessoas que estavam em volta da mesa, comiam com grande apetite e não falavam nada, sequer notaram sua presença naquele lugar.

Quando terminaram de comer, Nahman perguntou a Abrão: 
- Quando você vai embora?

- Quando? Eu... irei amanhã - respondeu Abrão levemente confuso.

E no dia seguinte, depois do almoço, quando faltava apenas uma hora para a partida, Abrão decidiu fazer um pedido, pedido este pelo qual havia viajado para cá, aproveitando que Nahman ficara sozinho com ele no quarto.

- Me escute, eu tenho um pedido para você - gaguejou Abrão virando-se para o homem com um suspiro de súplica e submissão.

- Eu tenho um pedido, - acrescentou, ao perceber que Nahman aguardava sua pergunta, - eu pensei ... eu e minha esposa pensamos em pedir para você nos ajudar com alguma coisa, com uma pequena quantia, para que possamos comprar produtos para a loja, porque sem a loja estaremos realmente perdidos. Não temos dinheiro sequer para uma única refeição, e assim, com a ajuda de Deus, nós o recompensaremos com grande gratidão e um dia lhe devolveremos até o último centavo.

- Se eu pudesse, certamente lhe daria - respondeu Nahman calmamente. - Mas estamos vivendo tempos muito ruins. Eu ainda posso lhe dar dois ou três rublos. Que culpa tenho eu por você ser pobre? Mas como nós somos seres humanos e também judeus, e também somos parentes... Muitos vêm até mim assim como você, alguns são parentes, outros não são, todos são pobres, sem dúvidas, mas por outro lado, eu não posso me desfazer dos meus bens, pois graças a Deus, eu tenho com quem gastá-los, se é que você me entende?

Abrão não respondeu nada, mas fingiu dizer: eu entendo, eu entendo, você deve estar certo.

- Três rublos eu posso dar a você - acrescentou Nahman num tom de apoio. - É verdade que é uma quantia respeitável levando em consideração o estado do comércio neste momento, mas, apesar de tudo, eu lhe darei os três rublos. - E após essas palavras, ele pegou três rublos do bolso e os entregou a Abrão. - Que o Senhor te salve e não precise mais recorrer a parentes.

- Obrigado! - gaguejou Abrão, com voz trêmula e sufocado em lágrimas. Seu rosto estava contorcido por um sorriso de submissão e dor, lágrimas escorriam de seus olhos.

Nesse momento, Rebeca, a esposa de Nahman, entrou na sala. Ela viu as lágrimas nos olhos de Abrão e a nota de três rublos que ele segurava, e sentiu enorme pena ao perceber que uma parte de seus bens encontrava-se agora nas mãos de um estranho. Então, dirigindo-se a Abrão, que estava ainda levemente confuso, disse-lhe em voz suave: 
- Você já está de partida, certo? Não vá se atrasar!

- Sim, já estou de partida - apressou-se Abrão a responder com a voz estrangulada. - Chegou a hora - Que continue vivendo em paz e com prosperidade - acrescentou Abrão, enfiando sua palma na mão de Nahman a título de despedida.

- E à senhora também desejo paz e bênçãos todos os dias - disse Abrão a Rebeca. - E onde está seu filho mais velho? Que a paz esteja sempre com ele e Deus o torne sempre próspero. Fiquem todos em paz.

- Vá em paz! - Rebeca cumprimentou-o respeitosamente, e então, ele saiu.

Devo voltar para casa de mãos vazias? - pensou Abrão enquanto se sentava na sua charrete. - De mãos vazias saí de casa e de mãos vazias deverei retornar? Não, isso é impossível. Se o coração do meu rico parente endureceu diante da minha presença, certamente deve haver muitos misericordiosos entre os filhos de Israel.

Então ele decidiu tentar numa outra cidade, reunir um pouco de dinheiro, não como um simples mendigo, que Deus não o permita, mas como uma pessoa decente que o fogo levou à ruina.

E dessa forma, a charrete acabou levando Abrão a uma pequena cidade, e ao anoitecer ele entrou no Beit Midrash ${ }^{3}$ para a oração da noite. Após a oração, ele permaneceu no Beit Midrash em companhia das pessoas que gostavam de compartilhar conversas e notícias. Foi então que algumas pessoas, percebendo sua presença naquele lugar, aproximaram-se dele e o cumprimentaram, perguntando quem ele era, o que o trazia àquele lugar e para onde ele se dirigia. Passado algum tempo, Abrão se viu cercado por um grupo de pessoas ansiosas por ouvir noticias e novidades, e alguns quiseram ouvir detalhes do desastre que se tinha abatido sobre ele. Alguns até tentaram ser gentis com ele, detalhando na sua frente os nomes dos filantropos, que certamente não se recusariam em ajudar alguém que passou por tremendo desastre e foi atingido pelo fogo. Um deles o convidou para ir com ele à sua casa para comer e dormir.

No dia seguinte, Abrão saiu para visitar as casas dos tais benfeitores.

- Por favor, conceda sua excelência a sua graça para ajudar um pouco um homem que teve todos seus bens queimados - Com esta formulação ele se voltou para o benfeitor. - Há cerca de dois meses ocorreu um grande incêndio na minha cidade. O fogo consumiu minha casa e minha loja, e eu, minha esposa e nossos cinco filhos ficamos sem nada. Ajude-me, por favor, com quanto puder, Deus o abençoará por minha causa. Não faz

\footnotetext{
${ }^{3}$ Casa de estudos e orações, geralmente anexa à sinagoga.
} 
muito tempo, eu fazia caridade com os pobres, e agora Deus me colocou diante de uma experiência tão difícil.

As palavras de Abrão, provindas do seu coração, somadas à sua aparência, mostravam que ele não era um pobre como qualquer outro, senão que era um homem que fora atingido por uma forte tragédia, causaram tamanha impressão, que Abrão não recebeu nem uma moeda ou duas como os outros pobres, mas cinco ou dez e até mais. Nem todo o mundo deu o que deu de bom grado, Abrão reconheceu isso perfeitamente. Por vezes, as esmolas que recebeu pareceram-lhe como dinheiro que tinha sido entregue a contra gosto, no entanto, as pessoas deram, e ele aceitou com gratidão. Após três dias, quando ele deixou aquela cidade, juntaram-se aos três rublos que tinha inicialmente, mais quatro.

Em vez de seguir direto para sua casa, Abrão pegou um caminho sinuoso que o conduziu a outras cidades. Ele almejava reencontrar sua esposa e filhos não mais de mãos vazias, ao contrário, queria poder ajudá-los após ter percorrido tamanha distância. Abrão partiu para uma jornada que se estendeu por um mês, ao cabo do qual voltou à sua cidade e à sua casa carregando consigo trinta rublos escondidos na túnica.

A esposa e os filhos perceberam, pela sua expressão, que ele não tinha retornado de mãos vazias, e o receberam com grande júbilo e se alegraram com ele, deixando de lado todas as dificuldades que tinham sofrido ultimamente - não fosse pelos vizinhos que tiveram misericórdia deles, certamente teriam morrido de fome.

- Como estão Nahman, Rebeca e seus filhos? - Perguntou sua esposa, deitada num sofá improvisado de tábuas que se encontrava no quartinho onde ela e os filhos moravam, enquanto observava seu esposo cansado da longa jornada.

- Todos estão sãos e salvos - respondeu Abrão.

- E qual é a situação deles? - a esposa continuou perguntando.

- Qual é a situação deles? Oxalá tivéssemos nós um décimo e até um vigésimo do seu capital! Seu filho mais velho ficou noivo, ele já possui três mil rublos para começar a vida, e seu futuro sogro é uma das pessoas mais ricas da região.

- Então essa é mesmo a situação deles? - Sua esposa perguntou com admiração e orgulho. - Tão ricos eles são? E como é que está a Rebeca? Certamente deve estar mais gorda, não é? Não é por acaso que uma pessoa engorda de tanta fartura, mas e o que ela perguntou a meu respeito?

- Ah, ela perguntou como é que você está! 
- Você percebe, parentes distantes ou próximos, são sempre parentes. E não é que Rebeca, apesar de toda a sua riqueza, não se esqueceu de sua parente pobre. Que Deus possa abençoá-la.

- E quanto eles lhe deram? - Perguntou a Abrão depois de um momento com certo receio.

- Quanto eles me deram? -Eles não estão precisando ser recompensados por Deus. Lindos parentes, especialmente ele, ele que enriqueceu e se tornou um avarento, que briga até por um centavo - disse Abrão como se fosse experiente no assunto.

- Como? - Perguntou sua esposa assustada - Eles não te deram nada?

- Eles deram alguma coisa, eles não deveriam ter mais.

- E quanto você trouxe?

- Eu trouxe algum dinheiro, não se preocupe. Bem que você estava preocupada quando me enviou até nossos parentes ricos, pois você imaginou que sem a ajuda deles eu estaria perdido. Mas saiba que os parentes se preocupam consigo mesmos, mais ainda quando são ricos. Os ricos estão esquecendo que existe um Deus no mundo e que Ele pode, num instante, transformar um homem pobre em rico. E eu, graças ao bom Deus, tive sucesso na minha missão, mesmo sem contar com a ajuda dos nossos parentes ricos.

- E quem foi que lhe deu uma ajuda?

- Esta é a regra, minha esposa: Quem procura acaba achando!

A esposa de Abrão ficou impaciente com suas palavras.

- Nem todas as pessoas oferecem rublos, porém cinco ou mesmo dez centavos todo judeu está disposto a dar, acrescentou Abrão.

- Então, você foi pedir ajuda de porta em porta? - Sua esposa perguntou alarmada.

- E o que há nisso? - Respondeu Abrão com relutância. - Afinal, não voltei para nossa cidade como um pobre, porém como um homem honesto que teve seus bens consumidos pelo fogo.

- Você foi pedir esmolas de porta em porta - voltou sua esposa a dizer com a voz embargada enquanto lágrimas fluíam de seus olhos e voltou a dizer:

- Meu Deus, Meu Deus, por que o Senhor me pune tão duramente? Quais são meus crimes e pecados, Deus amado, para me conduzir a esta situação? Meu esposo se viu obrigado a suplicar por esmolas de porta em porta e meus parentes se esqueceram de mim, e por ser pobre, eles já não me consideram mais parte da sua família, eles se esqueceram dos pobres. Por quê, Deus, tanta provação? Coitada de mim, minha própria existência é uma humilhação. 
- Não é que ela voltou às antigas lamúrias e ao choro? ela não pode mais, ela não aguenta mais - disse Abrão com raiva. - Para você a honra é a coisa mais importante, você não quer saber de mais nada, mas saiba que eu consegui juntar, sabe quanto? Trinta rublos, sim, trinta rublos, e não como um pobre que coleta centavos, mas trinta rublos em alguns dias! Se quisesse, eu poderia ter arrecadado ainda mais! Mas não, eu voltei para casa! Mas você só sabe chorar e está preocupada com a honra. E aqui estão os trinta rublos, aqui eles estão na sua frente.

Abrão desamarrou o pacote de moedas que estava guardado dento de sua túnica e tirou fora os trinta rublos. Ao ver o pequeno tesouro sua esposa parou de chorar. Ela nunca tinha visto antes uma quantia assim de dinheiro. Mesmo sua filha mais velha ficou muito impressionada com aquela visão. A esposa se pôs então a dar conselhos sobre o que fazer com aquele dinheiro.

- Você vai dizer a todos que esteve com nosso parente rico o tempo todo, e que foi ele quem te apoiou com um pouco de dinheiro - disse a Abrão. - E recomendo também que poderíamos alugar uma loja pequena no mercado. Certamente a Golda me dará algumas mercadorias a crédito para a venda. Certamente o Todo Poderoso terá misericórdia e nós deveremos ser bem sucedidos a partir de agora!. Vamos alugar também um outro apartamento, maior e mais confortável que este. E você Abrão, arrume alguns alunos e assim poderemos encontrar nosso sustento com a bênção de Deus. Certamente o bondoso Deus não se esquecerá de nós. É verdade que nossa casa foi consumida pelo fogo, e ali foi que começou a nossa desgraça!

- Eu ainda haverei de reconstruir a nossa casa também - disse Abrão com confiança e coragem.

- Que o Senhor dê o bem, que nosso amado Deus manifeste sua bondade - disse a esposa. - Nosso Deus é benevolente, e nada passa desapercebido perante Sua presença. Ele pode aumentar nossa graça até que um dia cheguemos a reconstruir a nossa casa e a loja, até mesmo comprar muitas mercadorias e abrir uma grande loja como a de Haya, a viúva, ou até mesmo igual à loja de Golda. Alguma coisa é impossível para Deus? E então, você não terá que continuar sendo um professor, poderá se transformar num comerciante, um senhorio decente e um homem distinto. E por que não deveríamos ser tão bem sucedidos como os outros? Deus ainda nos ajudará da forma como desejamos e rogamos.

Poucos dias se passaram e a esposa de Abrão abriu uma pequena loja dentro do mercado, e também alugou um apartamento de dois quartos e ali foi morar com a família. 
Enquanto isso, ela passou a insistir com Abrão várias vezes, dizendo que já era hora de ele procurar por alguns estudantes, mas ele ficou em silêncio permanecendo de braços cruzados. Somente quando sua esposa passou a pressioná-lo com todas as suas forças, ele finalmente respondeu irado:

- Eu sei que já está na hora, mas eu preciso de tempo. Você ainda tem receio de que não teremos tempo para alcançar essa felicidade - ele acrescentou sombriamente.

- E por acaso você já se tornou um rico que não precisa mais ensinar? - indagou a esposa.

- Você me lembrou que eu sou tão feliz! - disse Abrão enquanto torceu os lábios com raiva - Eu nem quero mais ver uma sala aula!

- Eu sei que você gostaria de ficar parado curtindo o ócio, eu também gostaria de ficar quieta, comer e beber até ficar saciada, e dormir todas as tardes. Eu não entendo o que aconteceu contigo de repente, você sempre soube quais eram a suas responsabilidades, seu único interesse era exercer sua função de mestre com responsabilidade, mas agora? Para onde o diabo carregou seu espírito?

- Ser professor, trabalhar como um boi de manhã até a noite, para finalmente receber sessenta rublos que são gastos em sua totalidade para nossa subsistência! E agora nossa casa se queimou... Os outros estão reconstruindo suas casas, mas a nossa casa nunca será construída pois não temos nada.

- E o que podemos fazer? O Todo Poderoso tem nos afligido duramente. Nossos problemas são muito grandes. Provavelmente nossa amarga sorte nos obrigará, quando envelhecermos a peregrinar de casa em casa em busca de ajuda, coitada de mim! - a esposa chorou silenciosamente. - Mas o que podemos fazer?

Abrão tinha uma resposta para esta última pergunta, mas ele preferiu ficar em silêncio e nada respondeu a sua esposa.

Após alguns dias, Abrão desapareceu de repente de casa e ninguém soube para onde ele tinha ido. Sua esposa entendeu o motivo de seu desaparecimento: não havia dúvidas de que ele tinha saído atrás de ajuda, ele virara um mendigo disposto a andar pelo mundo. - Que coisa grudou nele desde o retorno de sua viagem e que não lhe deu descanso o tempo todo? - E a esposa de Abrão se debateu em lágrimas em seu quarto, pois não desejava ser vista por ninguém. Sua dor era grande, especialmente porque ela não podia revelá-la a mais ninguém. Ela teve que fingir para todos dizendo que Abrão tinha viajado para uma cidade distante, a convite de um de seus parentes, para ser ali professor, porque os moradores daquela cidade pagavam um bom salário aos mestres. 
Desta vez Abrão não poupou uma cidade sequer, indo de casa em casa onde moravam os filhos Israel, e não ficou indagando se os ocupantes dessas residências eram ricos ou pobres, bons ou maus e, no entanto, desta vez ele conseguiu arrecadar menos dinheiro do que na primeira viagem, fato este que lhe causou surpresa e o deixou muito triste.

Por isso ele aproximou-se de uma das casas e disse em tom de súplica:

- Estou pedindo uma ajuda, fui atingido por um incêndio, já fui proprietário de uma casa decente. Peço, por favor, por uma ajuda generosa e assim serão abençoados pelo Todo Poderoso.

E, no entanto, as pessoas lhe estenderam duas moedas e alguns, apenas uma.

- O quê? - Ele disse visivelmente magoado - Qual é a razão de dar tão pouco? mais ainda, quando vocês dão a todo mendigo um centavo ou dois?

- E por acaso você é o único no mundo? - Lhe responderam as pessoas. - Pessoas como você vêm até nós com frequência, e se fossemos dar a cada um deles de acordo a sua vontade, até mesmo os tesouros de Coré$^{4}$ não seriam suficientes para cobrir os pedidos!

Abrão não disse nada, e deixou a casa engolindo sua ira. Em outra casa, uma casa que visivelmente não pertencia a uma família rica, também deram a Abrão apenas um centavo.

- Um centavo? - Surpreendeu-se Abrão - É muito pouco, minha casa foi consumida pelo fogo!

- Então sua casa foi consumida pelo fogo? - Isso nós já sabemos! - Estes pobres nunca estão satisfeitos. Sempre é preciso dar e dar. Por outro lado, não se pode saber quem é mais rico, se o pobre que pede esmolas ou aquele que dá.

- Vocês tem inveja dos pobres? - perguntou Abrão com um amargo sorriso e com uma pontada de maldade no coração. Ele sabia que sua vestimenta decente não lhe dava a aparência de um pobre simples cuja casa teria sido consumida pelo fogo, e essa mesma aparência acabava provocando aqueles comentários maldosos. Por isso concluiu que seria necessário substituir suas roupas por trapos, como o resto dos pobres usavam.

- Que Deus os coloque diante da mesma provação que colocou a mim mesmo, e então vocês saberão... - Amaldiçoou Abrão àquelas pessoas em seu íntimo.

\footnotetext{
${ }^{4}$ Coré foi um personagem bíblico mencionado no livro de Números, capítulo 16.
} 
Abrão continuou suas andanças e, muitas vezes, as pessoas não lhe davam nada, ou porque eles nada possuíam, ou por que eles simplesmente não queriam dar. E assim Abrão foi vagando pelas cidades por alguns dias, ficando com as pernas cansadas, indo de casa em casa e recebendo apenas algumas moedas de um centavo, que ele ia juntando num pequeno saco. E ele foi peregrinando de uma cidade a outra, o que deixou sua alma amargurada vendo as pessoas cada vez menos dispostas a lhe estender uma ajuda.

Desde então, passou a se alimentar oras com fatias de pão que ele carregava, oras com sobras de comida que estranhos lhe ofereciam, dormindo sobre o banco do Beit Midrash, juntando centavo a centavo e guardando o saco de moedas dentro de sua túnica. Após tantas andanças, suas vestes ficaram surradas e puídas até transformar-se em trapos. Seu rosto emaciado e sua voz cansada passou a expressar súplica e submissão, tal como os pobres como ele imploram. Mesmo assim, apesar de seu visível estado de degradação, ele ainda não se sentia parte da grande massa de mendigos, ele era vítima de um incêndio, ainda sentia-se parte de uma outra categoria de pedintes.

Com a chegada da primavera, aproximavam-se os dias da comemoração da Páscoa, e Abrão que já fazia mais de um ano que andava peregrinando atrás de ajuda, chegou a um vilarejo próximo de sua cidade natal. A umidade que se estendia pela região, a neve que derretida no mercado e os raios do sol brilhante que o aqueciam, lhe trouxeram a recordação do tempo em que tinha sido um professor, quando ensinava seus discípulos, esse duro trabalho que ele decidiu abandonar para poder, finalmente, sair da sala de ensino escura e estreita, e caminhar como um homem livre; a conversar com seus colegas professores, debatendo com eles sobre qualquer assunto, apenas por diversão. De manhã e à noite ele ia até o Beit Midrash afim de rezar e estudar com o intuito de expandir seu conhecimento sobre as orações, o que, frequentemente, lhe despertava um grande prazer, e depois das orações, ele ficava por um longo tempo para ouvir as notícias e os relatos com grande satisfação, sem ser incomodado pelos estudantes, que nessas horas estavam brincando na casa de estudos. Quão importantes eram aquelas horas de liberdade após o longo inverno e a árdua tarefa que tinha desempenhado no trabalho escolar junto a seus discípulos. Essas memórias, que surgiram em sua mente como uma névoa, despertaram em seu coração, repentinamente, um sentimento de saudade de sua vida passada e um sentimento de tristeza pelo que se perdeu.

- Oh! - suspirou Abrão profundamente. - Não há muito tempo eu era uma pessoa comum, e agora sou um pobre homem que peregrina de porta em porta, um errante, distante da minha casa, da minha cidade. Oh meu Deus! 
E naquele instante, ele desejou voltar para casa, e por isso começou a andar chegando a sua cidade três dias antes do início da Páscoa. O coração de sua esposa contraiu-se com grande dor quando viu o marido chegando em casa ao meio-dia (sua filha mais velha ficou em seu lugar na loja e ela voltou para casa para almoçar). Ele havia mudado muito desde que tinha saído de casa. Suas costas curvadas estavam ainda mais dobradas, a pele de seu rosto tinha escurecido e estava agora suja, e suas pálpebras estavam vermelhas.

- Abrão! - ela exclamou, pulando em sua direção e elevando a voz. Depois ela desmoronou e caiu na sua frente de olhos fechados. Muito Cansado, Abrão sentou-se num banco no canto, e permaneceu ali silencioso enquanto observava a cara de espanto de sua esposa.

- Abraão! - sua esposa voltou a chamar depois de um instante, quando abriu os olhos, e começou a soluçar. Então ela perguntou: - Onde você esteve o tempo todo? Pobre de nós! Oh meu Deus! Olhem para ele, um homem miserável que se viu obrigado a peregrinar de porta em porta atrás de ajuda. Olhe para você, Abrão, será que você perdeu qualquer senso de vergonha? Você deveria ter piedade de nós! Você é um assassino! Não! Deus já não está mais em seu coração! Você está nos envergonhando, e desta forma não poderemos mais andar fora de casa. Nós temos uma filha que já está na hora de casar, mas quem é que vai querer casar com a filha de um mendigo? Todo mundo já deve estar à par do seu triste destino. No início, eu tentei despistar, eu disse para as pessoas que você foi para longe para lecionar, mas a verdade já se espalhou por todos os cantos. As pessoas já descobriram a verdade, pois já viram você mendigando de porta em porta e a noticia já se espalhou por toda a cidade. Ai de mim! Infelizmente para mim, meu esposo transformou-se num pedinte que vai mendigando de porta em porta. Como você chegou nessa situação? O que é que você deseja? Você não quer ser mais um professor? Sou eu que estou te forçando a ser? Recobre a razão e a honra e volte para casa. Não te exigirei que faças alguma coisa, nos sustentaremos com o que o Senhor Todo Poderoso nos prover. É incrível o que um homem é capaz de fazer a si mesmo! Você era um homem decente, honesto, preocupado pelo seu sustento e, de repente, você se transformou num pedinte. Meus problemas são muito grandes, não preciso que o rótulo de mendigo cole em você!

Assim, a esposa de Abraão não cessou de desabafar sua amargura enquanto ele permaneceu cabisbaixo e silencioso. No fim, ela irrompeu em lágrimas e ele abaixou ainda mais a cabeça permanecendo ainda mais em silêncio. Quando a esposa parou de 
chorar, ela levantou, aproximou-se do fogão e tirou do mesmo um cozido que despejou dentro de uma tigela, colocando-o à mesa coberta com uma toalha grossa preta.

- Lave as mãos que lhe servirei o almoço, certamente você deve estar com fome disse para Abrão com voz fraca.

Ele lavou as mãos e sentou-se à mesa sem falar nada e comeu. Enquanto comia, sua esposa olhou para ele da cabeça aos pés, até que ele também olhou para si mesmo várias vezes, com um olhar visivelmente constrangido.

- Foi com estas roupas que você passou por todas as cidades? Alguém viu ou reconheceu você? - Ela lhe perguntou com decepção.

Ele não respondeu à pergunta dela, e permaneceu com a testa franzida.

- Vá se deitar e descanse um pouco da longa estrada, pois você deve estar cansado, já que todo o longo percurso você fez a pé - lhe disse sua esposa enquanto se preparava para recitar a benção dos alimentos.

Ele ficou parado por algum tempo, depois levantou-se e foi ao canto da sala, e estava prestes a deitar no banco parado ali.

- Deite-se na cama - disse sua esposa, então ele decidiu seguir seu conselho. Ao se deitar, sentiu abaixo de si uma cama macia que ele não conhecia fazia muitos meses, então se deitou confortavelmente. Mas de repente ele percebeu que sua esposa o observava, então ele fechou os olhos. E sua esposa, que estava em pé à porta, suspirou profundamente e saiu.

Abrão adormeceu rapidamente. A filha mais velha, que não demorou a voltar da loja, encontrou-o dormindo e se deteve para olhar para seu rosto por um longo tempo, depois começou a chorar em silêncio, mas lentamente seu choro engasgado ficou mais alto, até que finalmente Abrão acordou. Ele olhou em sua volta por alguns instantes, surpreso com que que estava acontecendo.

- É você, Dina? Por que está chorando? - Ele disse finalmente.

- Ai, ai, ai - soluçou Dina, - Como não haverei de chorar se meu pai tornou-se um mendigo que pede esmolas de porta em porta?

Abrão afastou dela seu olhar zangado.

Nesse momento, sua esposa chegou em casa trazendo um pequeno pacote de roupas.

- Por que está chorando? - a mãe repreendeu Dina, olhando oras para a filha e oras para Abrão.

- Ai, ai, ai, - lamentou a garota - E como não haverei de chorar? 
- Que nossos inimigos se lamentem, mas por que você está se lamentando? Você é minha primogênita, uma filha inteligente! Você está chorando como se estivesse enlutada pela morte do seu pai, que Deus não o permita! Sendo assim, você não tem nada a se lamentar. Papai voltou e nunca mais se afastará de nós. Ele foi até a casa dos nossos parentes para pedir-lhes uma ajuda para a construção da nossa casa. O que há de mal nisso? Ele era um professor e continuará sendo um professor com a ajuda de Deus. Aqueles que desejam nosso mal não poderão se contentar com a nossa tristeza. Mas você é uma filha ingrata. Se você demonstra tanta ingratidão como poderei eu ver as suas núpcias? Como é triste a minha sorte!

Após ouvir sua mãe, Dina foi até um dos cantos da sala, escondeu o rosto com as mãos e chorou em silêncio enquanto sua mãe permaneceu atordoada na sala por uns instantes.

Após algum tempo, ela dirigiu-se a Abrão e lhe disse:

- Tenho uma proposta para ti. Há alguns dias um homem passou pela loja querendo vender um capote e um par de calças em bom estado, estão quase novos. Veste-os e se eles ficarem bem em você, os comprarei imediatamente. Eu já me antecipei, fechei a loja e trouxe assas vestes até aqui. Experimente-as, por favor!

Abrão desceu da cama submissamente e, sem dizer uma palavra, despiu seu capote velho e remendado e ficou com a túnica que estava suja e muito puída.

- Tire essa túnica - disse a esposa.

Abrão olhou para ela com um olhar visivelmente embaraçado.

- O que está ocorrendo? Você está com pena por ter que tirar essa túnica dourada? - Surpreendeu-se a esposa - Tire essa túnica e assim Dina poderá lava-la; não pode mais ser usada no estado em que está. - Mas Abrão se recusou olhando para sua esposa com ar de teimosia, como se tentasse se defender. Somente então sua esposa entendeu a razão de sua recusa: dentro daquela túnica puída ele guardava o monte de dinheiro, e por isso se recusava a se desvestir. O coração da esposa estremeceu quando ela viu que Abrão estendia a mão para pegar seu velho capote com a intenção de vesti-lo novamente.

- Para que você quer esse capote? - sua esposa perguntou decepcionada Experimente as roupas que eu trouxe, nem que seja sobre a sua túnica.

Abrão vestiu silenciosamente o capote e as calças que sua the estendeu e não voltou mais a tira-los. E Dina pegou as roupas velhas e as escondeu.

Nos três dias que antecederam à festa de Pessach, Abrão não deixou a casa ajudando sua filha e sua esposa, que estavam ocupadas nos preparativos para a festa. Ele 
as ajudou a transportar os pesados moveis de um lugar para outro, passou a enxada no piso de terra dos quartos, e realizou com satisfação uma série de outros trabalhos domésticos com rapidez exagerada, ajudando não apenas sua esposa, mas mesmo seus filhos.

Na primeira noite da festa, Abrão saiu de casa pela primeira vez para ir à sinagoga. Ele passou sem olhar para ninguém até chegar na parte de trás perto do forno, sentou-se no banco e rezou compenetrado, sem tirar os olhos do siddur ${ }^{5}$ sequer por um instante. Após as orações, alguns de seus conhecidos se aproximaram dele e lhe estenderam a mão para cumprimenta-lo. Alguns também lhe perguntaram quando ele havia retornado à cidade, mas ele respondeu a todos com poucas palavras. Ele sabia que todas aquelas pessoas estavam informadas a respeito do que ele tinha feito nos últimos tempos quando se afastara da cidade, e que elas achavam que o que ele tinha feito, era algo extremamente humilhante, por isso os observou com ira. Mais tarde, quando ele se sentou à mesa com sua família para a celebração do Pessach, sua esposa perguntou enquanto ele estava comendo:

- E a quem dos nossos conhecidos você viu na sinagoga?

- Eu vi a todos eles, todos se aproximaram para me cumprimentar.

- Foram muitos o que foram te cumprimentar?

- Muitos? Ao menos metade dos que se encontravam na sinagoga. E por acaso você acha que eles estavam envergonhados com a minha presença ou que eu deveria me sentir envergonhado com a presença deles? Você acha que essa foi a razão pela qual não sai de casa por três dias, por causa da vergonha? E do que eu tenho para me envergonhar? O que eu fiz aos olhos deles, certamente não é digno, se não for, então que eles não o façam, mas eu tenho a liberdade de fazer aquilo que eu desejo e ninguém tem o direito de me recriminar. Se o que eu fiz está errado, então isso vai me prejudicar, e os outros não tem o direito de me julgar.

A esposa e a filha abaixaram a cabeça e permaneceram em silêncio. Ele, ao contrário, começou a falar compulsivamente pela primeira vez desde a sua chegada.

- E quem são eles? - acrescentou um momento depois - e por acaso eles não são pobres? Na verdade, são mendigos que morrem de fome dez vezes por dia, e mesmo assim eles não perdem a posse. Pobres, porém orgulhosos. O Todo Poderoso certamente recriminaria tal atitude. O pobre deve conhecer seu lugar neste mundo. Eles são

\footnotetext{
${ }^{5}$ Siddur é o livro das orações diárias que são recitadas três vezes ao dia.
} 
orgulhosos... Eu certamente sou dez vezes mais rico do que eles. Certamente eles nunca viram na vida um saco de moedas como o que eu consegui juntar. - Após essas palavras, Abrão parou de falar e mordeu o osso que estava em sua boca com uma expressão de raiva. E naquela noite, não voltou a falar mais nada. Abrão escondeu o dinheiro de sua esposa com muito cuidado, deixando-a extremamente desconfiada, pois em sua imaginação, ela tinha decido que esse dinheiro seria usado no dote de casamento de Dina, a filha primogênita.

Um dia ela decidiu abrir seu coração e contou a Abrão sobre sua preocupação com Dina.

- Eu não preciso lhe dizer que não posso juntar um centavo sequer da loja para o casamento de Dina. Ela mesma entrega para o sustento da casa todo o dinheiro que ganha com as costuras e as pinturas de letras em tijolos, enquanto que ela mesma nem sequer tem uma túnica inteira. E você sabe que no mundo inteiro é impossível encontrar uma filha como ela. Sem ela e sua ajuda eu estaria perdida. Ela é uma boa dona de casa, ela toma conta das crianças, costura, faz reparos e remendos nas roupas, ela tem verdadeiramente mãos de ouro e, no entanto, é uma noiva pobre, se ao menos eu pudesse lhe dar um dote! Com esse dote ela poderia ter um certo conforto já que, ela veio para este mundo sem sorte alguma.

Abraão ouviu as palavras de sua esposa, como se estivesse compartilhando de sua tristeza.

- E você ... por acaso você não tem dinheiro algum? - Lhe perguntou.

- Eu? - respondeu Abrão com embaraço - Se eu não tenho? Eu tenho cinquenta rublos.

Ele mentiu, pois o dinheiro que tinha juntado chegava a oitenta e dois rublos. Sua esposa não acreditou nele, e lhe disse:

- Nada mais do que isso? É uma quantia pequena. Mesmo assim, será para Dina de grande valia. Esse valor cobrirá metade do dote, e a outra metade virá com a ajuda do Todo Poderoso!

- O dote para Dina? - Gaguejou Abrão - mas para que temos que nos apressar? Dina ainda é jovem.

- O que? Ela é jovem? O que é que você está dizendo Abrão? Você está louco? Quando eu tinha a idade dela já era mãe de um bebê de um ano. Ela já é uma jovem de dezoito anos. Há três anos que não tenho sossego pensando de que forma poderei casala. Ela também anda muito triste, pois sabe qual é seu triste destino. Que culpa ela tem de 
ter nascido minha e não a filha de uma mulher rica? É por acaso não é merecedora de ter uma vida feliz e confortável? Ela não é uma moça qualquer, é uma pérola, uma joia é ela! O que eu não faria para vê-la feliz? Mesmo a minha vida eu daria por ela!

Abrão ouviu as palavras de sua esposa em silêncio.

- Embora - acrescentou sua esposa - seria necessário comprar um pouco de mercadorias para a loja; a loja está quase vazia e simplesmente já não temos o que vender para nosso sustento... mas ... seja o que for... Deus proverá ajuda. Nós não podemos tocar nesse dinheiro. É melhor entrega-lo em sua totalidade nas mãos do senhor Mordechai, ele tomará conta desse dinheiro até o dia que seja por nós solicitado a nos devolve-lo. Essa é a única saída!

A medida em que sua esposa se debruçava cada vez mais sobre a sorte de sua filha mais velha, o embaraço de Abrão só aumentava. E sua esposa continuou falando:

- Onde está o dinheiro? Mostre-me o dinheiro.

- Por quê? - ele respondeu com raiva - por que você tem que vê-lo?

- Por que sim - disse sua esposa com mágoa. - E por que eu não poderia vê-lo? Por acaso você esconde seu dinheiro de mim? Por acaso eu não sou sua esposa? A quem o homem deve mostrar seu dinheiro, se não a sua esposa? Ai, ai de mim! - E de repente as lágrimas escorreram de seus olhos e ela começou a chorar.

- Você sempre chora - disse Abrão visivelmente zangado, e com raiva ele levantou de seu assento. - Teria sido melhor se eu não tivesse voltado aqui.

Três dias depois, Abrão entregou a sua esposa os cinquenta rublos.

- Aqui está o dinheiro! Você pode se enforcar com ele! - disse Abrão com grande ira.

Durante esses três dias, sua esposa tinha falado e chorado até que ele cedeu a seu desejo. E depois que esse dinheiro lhe fora entregue, ela nunca mais o devolveu.

- Por que você teria que manter esse dinheiro contigo? Você poderia perdê-lo ou pior ainda, ele poderia ter sido roubado. É melhor que eu o esconda até que consiga entrega-lo em custódia ao senhor Mordechai - falou a esposa, e sem esperar pela sua resposta foi rapidamente até seu quarto e ali o escondeu dentro de um baú. E a noite, quando Abrão foi rezar na sinagoga, ela tirou o dinheiro do baú e escondeu-o em outro lugar secreto, até ficar satisfeita com seu sucesso.

E Abrão, depois que sua esposa tirou dele o dinheiro, passou a ficar melancólico e enfurecido o tempo todo. Ele tinha decidido retornar para sua casa em busca de paz de espírito, mas eis que seus próprios familiares perturbavam seu sossego. Eles não se 
importavam com ele, eles sequer o levavam em consideração. Eles apenas se importavam com o dinheiro que ele tinha juntado, se não fosse por isso, já o teriam expulsado de casa. Se o respeitassem como marido e como pai, não teriam tirado seu dinheiro à força. Se ele tivesse querido dar, ele daria, mas ele também poderia ter se recusado a entregar o dinheiro, tudo seguindo seu desejo e vontade! Recolher esmolas de casa em casa é um ato desprezível a seus olhos, já o dinheiro coletado dessa forma lhes agrada enormemente! Foi então que Abrão percebeu que ele não deveria ter voltado para sua cidade e para sua casa.

Depois destes acontecimentos, em lugar de se mostrar submisso à sua família, ele começou a provocá-los. Inicialmente, sua esposa e Dina ficaram felizes com a mudança que ele aparentava mostrar, sinal de que Abrão tinha voltado a exercer seu papel de marido e pai em casa. Mas essa atitude lhes deu motivos para ter medo dessa repentina mudança.

Depois que a comemoração de Pessach passou, a esposa de Abrão começou a permanecer o dia inteiro em sua loja. A segunda filha depois de Dina voltou a seu trabalho como costureira, e os dois filhos pequenos começaram a frequentar novamente o Beit Midrash. Dina passou a fazer todo o trabalho de casa, além de costurar. Apenas Abrão não encontrou uma ocupação, e por isso, sentou-se desolado em sua casa durante todo o dia. Com o avanço da primavera, a vida ganhou um novo despertar, os judeus saíam de suas casas, como se tivessem acordado de um rigoroso inverno, com novas esperanças de encontrar algum sustento no mercado para superar uma vida de privações e preocupações. Essa vida entediante deixou Abrão abalado, fortalecendo nele o desejo de abandonar sua casa e a cidade.

- Eu vou embora, já estou decidido. Eles vão conseguir se sustentar sem mim. Eu sei que eles bem que gostariam que eu trabalhasse e os ajudasse no sustento da casa, eu sei. Por outro lado, eles também querem tirar de mim o restante do dinheiro que eu guardei. Eu não vou mais permitir que o façam. Eles não me dão sossego, sempre com suas preocupações, sempre pensando neles e apenas neles mesmos. Quando eu não estou aqui estou pelo menos em paz comigo mesmo. Eu irei sozinho e não haverá ninguém para tomar de mim o pouco dinheiro que, com grande esforço, consegui.

Abrão ansiava cada vez mais pela vida de um nômade. Sua família passou a ter receio dele e eles ficaram tristes e apreensivos, e essas atitudes o incitaram ainda mais a tomar um novo rumo na sua vida. Numa ocasião, durante a refeição da noite de sextafeira, Abrão repreendeu sua esposa e lhe disse: 
- Por que você está me olhando assim?

- Como eu estou olhando para você? Como eu deveria olhar para você? Eu olho para você do mesmo modo como olho para as outras pessoas.

- Mmm - rosnou Abrão, ficando em silêncio por um instante.

- Eu sei porque vocês olham para mim assim! - disse ele com raiva - vocês estão incomodados porque eu não trabalho para vocês. Vocês gostariam que eu trabalhasse como um escravo cananeu, que trabalhe para vocês como um burro, eu sei, eu sei, mas não será assim! Eu já trabalhei o suficiente para vocês! Por quinze anos trabalhei como um boi, e para quem? para vocês bastardos! e eu recebo de vocês alguma coisa em troca? Não serei mais um idiota, não vou mais mexer um dedo por vocês. Não ficaria comovido se os visse morrer agora na minha frente. Se vocês querem mais dinheiro de mim então... Estou saindo desta casa e nunca mais em sua vida voltarão a me ver. Assim será!

Ao ouvir estas palavras, sua esposa e Dina, e depois as outras crianças irromperam em forte choro.

- Por que vocês estão chorando? - irrompeu Abrão furioso, pulando no lugar como um louco. - Vocês choram? Se não pararem de chorar, então os deixarei imediatamente e nunca mais voltarão e me ver! Sairei daqui e me afogarei, ou me enforcarei, lhes causarei a maior humilhação do mundo, então saberão o que é chorar de verdade! E então, vocês não vão parar de chorar? Eu vou enfiar esta faca no meu coração! - ele pegou uma faca afiada que estava sobre a mesa. Ao ver este ato, todos ficaram em silêncio de tanto medo.

Alguns dias depois, Abrão desapareceu repentinamente da casa sem deixar qualquer vestígio e nunca mais foi encontrado. Ele atravessou cidades e passou a coletar esmolas de porta em porta. Desta vez, decidiu pedir esmolas para uma noiva pobre, e muito se lamentou por não ter em mãos uma carta do rabino de sua cidade, na qual estaria atestado ser ele o pai de uma filha em idade de casar, pois então, as esmolas certamente seriam generosas.

Abrão tornou-se solitário, ele pedia esmolas também para si, pretendia que todos deviam dar-lhe, porque, segundo sua intuição, aquelas pessoas tinham dinheiro, e ele pretendia juntar uma boa quantia. Parecia que ele vivia num mundo e, as outras pessoas num outro mundo, e esses dois mundos estavam sempre em guerra: ele desejava receber esmolas, porém eles, se recusavam a dar. Ele passou a se valer de todo tipo de artifícios para tirar das pessoas alguns centavos, e eles tentavam de todas as formas se livrarem de sua insistência. Ele se viu odiado por todo o mundo, e o mundo inteiro o desprezava. Ele deixou de acreditar nas pessoas. Não acreditava que se pode amar não só a si mesmo, mas 
também aos outros. Não acreditava que não se pode odiar a quem gosta do que ele mesmo queria desfrutar. Ele também não acreditava, que todas as pessoas do mundo tem coisas boas além de se ocuparem com coisas materiais.

E assim transcorreu o tempo, e seis anos tinham se passado desde que Abrão abandonou sua casa e passou a coletar esmolas de porta em porta. E nesse mesmo ano Abrão foi atingido por uma tragédia: ele perdeu a visão dos dois olhos, ficando completamente cego. Seus olhos que tinham adoecido nos últimos anos, se deterioram ainda mais, e finalmente o cegaram, e o mundo de Abrão escureceu para sempre.

Quando se viu solitário num mundo escuro, seu coração se encheu de medo e ansiedade, como se estivesse vagando à noite pela floresta. A escuridão se mostrava assustadora, e ele temia a cada momento ser atacado por algum animal feroz. Também percebeu que não possuía nem um punhal. A escuridão o enchia de pavor. Ele passou a temer quaisquer passos ou até mesmo o barulho de uma bicicleta passando. Pareceu-lhe também que os outros não mais percebiam a sua presença, porque é da natureza humana se preocupar apenas com si e não com os outros, então imaginou também que as pessoas poderiam tropeçar nele e machuca-lo. Por isso ele decidiu buscar a proteção de um outro mendigo, um jovem que o protegesse de qualquer tragédia ou ataque. Ele decidiu entregar sua vida nas mãos desse jovem, porém, na verdade, nem nele ele confiava. Pareceu lhe várias vezes que esse jovem levava-o direto para o abismo ou para abaixo das rodas de uma carroça, e quando sentiu a mão do rapaz que o segurava aproximando-se do seu peito, lugar no qual ele escondia suas moedas, temeu muito que este descobrisse suas riquezas e então que seu segredo fosse descoberto. Às vezes, parecia-lhe que o rapaz já devia saber que ele escondia dinheiro e que, ele pretendia conduzi-lo a um dos lugares escuros para matá-lo e roubar seu dinheiro. Embora ele fosse um rapaz jovem, certamente era capaz de atingir um cego com uma faca ou com uma pedra. Era possível ainda, que esse jovem tivesse revelado aos outros o segredo de seu dinheiro, então ele imaginou que os outros também poderiam cobiçar suas moedas e, por isso, poderiam tentar assassina-lo.

Com o passar do tempo, Abrão foi se habituando com sua condição de cego. Ele percebeu, que as pessoas não estavam à sua espreita o tempo todo para matá-lo. Ele também conseguiu esconder de seu assistente o saco de moedas que carregava em sua túnica, e se este ou os outros mendigos conseguiam lhe tirar alguma coisa, eram apenas alguns centavos que eles encontravam nos bolsos de seu capote. Por outro lado, ele percebeu que sua cegueira tinha um lado bom: as pessoas sentiam pena dele e lhe davam e abriam a mão para ajuda-lo. 
Certa vez ele estava sentado na beira da estrada pedindo esmolas. Ele encontravase sozinho pois seu assistente tinha ido para algum lugar. Fazia muito tempo que Abrão não ouvia passos de pessoas se aproximando, pois não era comum a passagem de transeuntes naquele horário do dia. Foi então que seus olhos se abriram, e em sua mente correram uma profusão de pensamentos a respeito do dinheiro que tinha juntado naquele dia, do encontro que havia tido com um outro mendigo naquela manhã, e sobre os pingos de chuva fria que vinham caindo desde cedo. Ele se contraiu devido ao frio e encostou-se à parede onde estava sentado fechando os olhos com grande desejo de dormir. Ele se concentrou no saco de moedas que escondia e se deteve em pensamentos:

- Cento e cinquenta rublos... - em sua cidade natal, quem tem uma quantia assim, pode ser considerado um homem rico, e, no entanto, ele é considerado um pobre. Se ele quisesse poderia voltar repentinamente para sua cidade natal. Seus conhecidos certamente olharão para ele com pena: coitado do Abrão, ele virou um pobre mendigo cego, tenham piedade dele! Por que eles são proprietários de casas. Eles não têm um pedaço de cobre para dar como esmola, mas se veem como senhores importantes. E sua esposa? Quando o encontrasse certamente irromperia em choro ao vê-lo cego. As pessoas olhariam para ele com desprezo e raiva. Mas então eles conheceriam o verdadeiro Abrão, e nesse dia, não haveria quem não quisesse casar com Dina. Então ele viraria um visitante bem quisto, e nesse momento ele tiraria da túnica os cento e cinquenta rublos na frente da esposa, dos filhos e de todos os seus conhecidos, e ainda lhes diria com um leve prazer:

- Agora vocês percebem quem entre nós é o rico e quem é pobre? Vocês certamente, mesmo em sonhos, nunca viram uma quantia tão vultuosa. Agora vocês podem perceber que se eu quisesse, poderia ser um senhor privilegiado, dono de uma boa casa? E vocês, minha esposa e Dina, vocês ainda se envergonham de mim? Afinal, com o dinheiro que possuo, poderia, arrumar facilmente, um bom marido para Dina. Agora eu posso fazer tudo, e vocês nobres e privilegiados senhores, também com vocês eu poderia comprar o que eu quisesse em seus comércios, se quisesse. Porém venham me pedir um centavo em troca de seu suposto prestigio, e eu não lhes darei nada por ele. Continuem se vangloriando de serem senhores tão distintos, quando são, na verdade, apenas mendigos com ares de nobres. E vocês duas ainda se envergonham de mim? Estou muito triste em saber que vocês tem vergonha de mim! Por isso um centavo sequer receberão de mim. Saibam que eu tenho cento e cinquenta rublos.

Abrão regozijava-se ao pensar em sua pequena fortuna. Ele apalpou o lugar no qual escondia seu dinheiro. Ele imaginava ver muitas moedas sendo derramadas e 
correndo diante dele como um rio de ouro cujas ondas imponentes brilham com vigor. Esse brilho enche seu coração, e ele imagina estar ouvindo o ouro sendo derramado, e este é um barulho que muito lhe agrada.

Abrão começou a cochilar e sua cabeça estava apoiada em seu peito, quando repentinamente uma carroça que transportava um casal passou na sua frente sacudindo-o de seu breve sono. Ele cambaleou, coçou a cabeça e emitiu seu costumeiro chamado que para muitos já se tornara familiar:

- Deem uma esmola a um cego doente.

Uma noite, Abrão encontrava-se deitado sobre um monte de palha no albergue, sem conseguir pegar no sono. Ele virou-se de um lado a outro escutando o ronco do resto dos mendigos que ali dormiam. Normalmente ele dormia pouco à noite, com medo que alguém lhe tirasse o dinheiro. Também naquela noite, ele não conseguiu dormir, ele pensou a respeito de seu dinheiro, e estava ansioso para vê-lo. Ele observou a seu redor e constatou que todos tinham caído em sono profundo. Então afrouxou a camisa, e tirou lentamente algumas moedas de ouro com muito cuidado, para que ninguém escutasse o tinido das mesmas. Ele apalpou-as com cuidado e constatou que as oito moedas estavam ali. Mas de repente seu corpo estremeceu e ele cobriu as moedas com a palma da mão. Ele ouviu um leve movimento vindo do lugar no qual seu assistente dormia. De repente, o menino acordou e viu, à luz das velas que ele havia se esquecido de apagar, como o velho se apressava a esconder as moedas com as mãos trêmulas, duas das quais, ele pode notar, eram moedas de ouro.

- O velho demônio tem moedas de ouro - foi o pensamento que tomou conta da mente do jovem assistente, um jovem de treze anos que passara toda sua vida entre os mendigos.

- Por que você não dorme, velho - disse ele para Abrão com um leve sarcasmo. Este é um bom horário para contar dinheiro!

- Que seu pai seja atormentado pelo diabo - disse Abrão - Quem está contando dinheiro aqui? Onde você viu dinheiro? Você deve ter sonhado, seu bastardo, seu canalha! Como pode ter visto dinheiro se o quarto está na escuridão?

- A vela está acesa e eu estou acordado. Só os cegos não podem ver a luz das velas, e eu vi o dinheiro muito bem.

- Que o demônio penetre no peito de seu pai - amaldiçoou-o Abrão irado. - Seu ladrão, o diabo atormentará seu pai e seu avô! 
- O demônio está aqui - zombou o menino encantado com a fúria do cego - Você conta as moedas à noite, isso quer dizer que você tem muitas moedas, não é?

- Ladrão, bastardo, apóstata, onde viu o dinheiro? - que o diabo amaldiçoe seu pai! Eu não tenho dinheiro algum!

- A quem você quer enganar? Meus olhos viram perfeitamente quando você estava contando suas moedas - disse o jovem rindo mais ainda.

- Que moedas, seu ladrão? - Gritou Abrão, alarmado.

- E de que espécie são suas moedas? Por acaso você tem moedas de ouro? Você é um cego que quer que os outros o considerem um Rothschild. Não, a mim você não vai enganar! Eu vi com meus próprios olhos também aqueles rublos!.

- Que o diabo penetre em todos os seus ossos, apóstata, ladrão - gritou o cego pulando sobre o menino que escapuliu e conseguiu fugir para um canto. - Onde você está, bastardo, apóstata?

Os gritos do velho cego acordaram os outros mendigos.

- O que está acontecendo aqui? - perguntaram um ao outro ainda bocejando.

- É aquele cego, que o diabo o leve, é ele que não nos deixa dormir - respondeu um dos mendigos com relutância.

E quando a raiva de Abrão diminuiu, deitou-se novamente sem conseguir pregar os olhos. O silêncio tomou conta do quarto, e novamente se escutava o ronco dos mendigos invadindo todo o espaço. O garoto permaneceu num canto e não voltou a deitar em seu lugar de antes.

- Como o demônio cego se enfureceu, ele quer ser um Rothschild - pensou o jovem.

- Um ladrão, ladrão, que o diabo penetre no corpo do seu pai e do seu avô espumou Abrão tomado pela raiva.

- Rothschild, um Rothschild cego - o menino zombou dele. E assim a conversa continuou por mais alguns minutos, até que o jovem foi dominado pelo sono e ele voltou a dormir.

Mas Abrão não conseguiu mais dormir permanecendo acordado a noite inteira. Ele percebeu que as falas do jovem o tinham abalado. Ele voltou a apalpar suas moedas tentando se certificar que eram as moedas de ouro e não apenas os rublos. Pouco a pouco as suspeitas e o medo começaram a torturá-lo. Ele tentou afastar esses pensamentos que o atormentavam, sem, no entanto, ter sucesso. 
- É tudo mentira - falou Abrão para si mesmo em segurança. Afinal, eu mesmo havia trocado o dinheiro pelas moedas de ouro quando ainda enxergava, e o embrulho esteve escondido comigo desde então e ninguém o tocou. No segundo pacote há quarenta rublos em notas, além de dezoito rublos em moedas. Tudo está em ordem, não está faltando nada, pensou Abrão. - Ele passou a ser dominado novamente pelo medo - mas talvez meu segredo tenha sido revelado aos outros, e assim, uma noite quando estiver dormindo, alguém poderia me pegar de surpresa trocando minhas moedas de ouro por rublos, qualquer um deles pode fazer isso, são todos eles ladrões e assassinos! Ou até mesmo, o mais jovem entre eles, o próprio ladrão. Que milhares de raios quebrem a sua cabeça! Sim, quando uma pessoa está dormindo, tudo pode ser feito com ela. E talvez eles acabem me fazendo dormir com algum sonífero, e dos centro e vinte rublos que possuo agora, somente sobrarão quatro. Não! Não! - ele tentou se acalmar - isso não pode acontecer! Que o diabo penetre em todos os seus ossos, seu jovem ladrão! Aquelas são minhas moedas de ouro, sem dúvidas! Para obtê-las, tornei-me um pobre andarilho que mendiga de porta em porta. Só por elas saí da minha casa e, ainda, perdi a vista, e agora sou um mendigo cego, perdido e sofrido... Não, não, aquelas são minhas moedas de ouro! Se apenas pudesse vê-las com meus próprios olhos! Deus, por que tem me torturado desta forma? Muitas pessoas neste mundo vivem uma vida de riqueza e tranquilidade, e eu sou pobre, doente e cego. Meu Deus, por que você me fez um cego miserável neste mundo?

De manhã, quando os outros mendigos acordaram, eles encontraram Abrão muito zangado.

- O que foi que aconteceu contigo que gritou a noite inteira? - perguntou um dos homens?

Abraão mostrou-se contrariado e não respondeu nada.

- Eu lhes direi por que o cego gritou à noite - disse o jovem que acabara de acordar - Ele pretendia ser um Rothschild e eu não o deixei, e por isso ele gritou tanto.

- Que o diabo atormente teu avô, seu ladrão, assassino - disse Abrão com uma grande fúria, seu rosto parecia muito pálido e contorcido de raiva enquanto falava com o jovem.

- Vocês veem como ele está com raiva? - o menino continuou a zombar - ele quer ser Rothschild e mais ninguém, e o que eu poderia fazer com ele? Eu o vi à noite, quando ele estava contando as moedas à luz das velas, eu vi apenas alguns rublos, e ele quer que eu pense que ele é... hahaha - O garoto parou de falar quando de repente o cego deu um pulo. 
Abrão estava transtornado de raiva e seu rosto parecia amedrontador. Ele atirouse em direção ao jovem zombeteiro e quase o alcançou, mas o menino virou-se rapidamente para o lado. O cego o seguiu e o menino se afastou dele indo em direção ao outro canto do quarto, mas Abrão continuou perseguindo-o com persistência. Um grunhido escapou de seus lábios, e ele ergueu seus olhos.

- Fuja daqui, garoto, senão ele vai te matar - disseram os outros mendigos. E o garoto, cujo rosto estava pálido como o rosto de um morto, foi tomado pelo pânico, correu com todas as forças e abriu a porta, ele pulou para fora antes de ser pego pelo cego que quase o alcançou, e Abrão caiu com o rosto no chão.

- Oh, Oh, Oh - Abrão rosnou horrivelmente tomado pelo desejo de vingança, porém frustrado por não ser capaz de executa-la. O sangue escorria de seu nariz e uma de suas bochechas já estava de cor azul-escuro. Dominado pela raiva e pela dor, ele ficou estendido no chão sem forças para levantar. Pouco a pouco seu grito de raiva deu lugar a um choro estranho e terrível.

No fim da vida, Abrão era um homem velho, curvado e doente, que apenas despertava pena em todos aqueles que o viam. Ao estender a mão para pedir esmolas, ela tremia de vez em quando. Sua existência se resumia a pedir e mendigar, juntar um centavo e mais um, mas além disso, ele não tinha mais nada na vida. No fim, ele já não pensava mais em seu dinheiro, nem o contava mais, ele até tinha perdido a conta de quantas moedas possuía... Muito raramente sua mente era tomada por vagos pensamentos a respeito de suas posses. Naqueles instantes ele se lembrava de ter cento e vinte rublos num pacote escondido, e no outro à direta, escondido sob o peito, mais trinta rublos, e no pacote acima desse, quantos? Quantos? Ele já era incapaz de lembrar... 